\title{
Characterization of caseinomacropeptides released from renneted raw and UHT treated milks
}

\author{
C Ferron-Baumy 1, D Mollé 2, G Garric ${ }^{1}$, JL Maubois 2* \\ 1 ULN, Laboratoire de recherches, 50890 Condé-sur-Vire; \\ 2 INRA, Laboratoire de recherches de technologie laitière, \\ 65, rue de Saint-Brieuc, 35042 Rennes cedex, France
}

(Received 20 September 1991; accepted 31 December 1991)

\begin{abstract}
Summary - The kinetics of release of the glycosylated and carbohydrate-free forms of caseinomacropeptide (CMP) was studied in renneted raw and UHT $\left(140^{\circ} \mathrm{C}\right.$ for $\left.10 \mathrm{~s}\right)$ milks. The new chromatographic method utilized allowed quantitative determinations of both molecular forms. UHT treatment leads to a $40 \%$ decrease of the final content in glycosylated forms compared to the value determined in raw milk. The results obtained show that carbohydrate-free $\kappa$-casein constitutes $52 \%$ of whole $\kappa$-casein. When milk is UHT treated, $\beta$-lactoglobulin only seems to influence the release of the glycosylated form. Nevertheless, no conclusion can be drawn concerning the localization in the micellar structure of both molecular forms of $k$-casein.
\end{abstract}

milk / coagulation / rennet / glycosylated CMP / carbohydrate-free CMP / thermal treatment / UHT treatment

Résumé - Caractérisation des caséinomacropeptides libérés lors de la coagulation par la présure de laits cru et UHT. Grâce à une nouvelle méthode chromatographique permettant la séparation du caséino-macropeptide (CMP) résultant de l'action de la présure sur la caséine $\kappa$, les cinétiques de libération des formes glycosylées et non glycosylées du $C M P_{t}$ à partir du lait cru et du même lait traité UHT, chacun soumis à l'action de la présure, ont pu être quantifiées. Le traitement UHT conduit à une diminution d'environ $40 \%$ de la teneur finale en CMP glycosylé par rapport à la valeur déterminée sur le lait cru. Les résultats obtenus précisent la répartition entre formes glycosylées $(42 \%)$ et non glycosylées (58\%) de la caséine $\kappa$. Ils démontrent également une influence très préférentielle de la $\beta$-lactoglobuline sur la libération des seules formes glycosylées de cette caséine lors du chauffage du lait. Mais ils ne permettent pas de conclure quant à la localisation de ces formes glycosylées au sein de la structure micellaire.

lait / coagulation / présure / CMP glycosylé / CMP non-glycosylé / traitement thermique / UHT

* Correspondence and reprints 


\section{INTRODUCTION}

Rennet coagulation is a result of a 2phase mechanism: enzymatic splitting of one of the milk caseins, $\kappa$-casein, followed by an aggregation of the resulting paracasein micelles into a network in which calcium salts are involved. $\kappa$-casein is a heterogeneous protein with 2 main genetic variants, $A$ and $B$, each having at least 7 other molecular forms differing in their glycosylation level (Walstra and Jenness, 1984). The proportion of carbohydrate-free molecules of $\kappa$-casein is estimated at between 33\% (Walstra and Jenness, 1984) to $40 \%$ (Vreeman et al, 1986). The more recent model proposed for the structure of casein micelles (Schmidt, 1982) shows most of the $\kappa$-casein molecules on the outside; the micelles have a hairy surface due to their protruding C-terminal ends (Walstra and Jenness, 1984). Numerous recent studies (Yoshikawa et al, 1978; Kudo et al, 1979; Walstra, 1979; McGann et al, 1980; Mehaia and Cheryan, 1983) favour an external localization of glycosylated $\kappa$-casein, while Wheelock and Knight (1969) and Sinkinson and Wheelock (1970) conclude that the localization is internal.

Heating of milk induces formation of a $\beta$-lactoglobulin - $\kappa$-casein complex which reduces the accessibility of the $\mathrm{Phe}_{105}$ Met $_{106}$ bond to chymosin (Dalgleish, 1990; Reddy and Kinsella, 1990). Consequently, the final amount of the released $\mathrm{C}$-terminal part of $\kappa$-casein (caseinomacropeptide, $\mathrm{CMP}_{t}$ ) is reduced proportionally to the intensity of the heat treatment previously applied to milk.

Using a new chromatographic method recently proposed by Léonil and Mollé (1991), we have shown that heating milk to $140{ }^{\circ} \mathrm{C}$ for $10 \mathrm{~s}$ led to an $18 \%$ decrease in $\mathrm{CMP}_{\mathrm{t}}$ release by chymosin (FerronBaumy et al, 1991).
As the method of Léonil and Mollé (1991) allowed separation of the carbohydrate-free form of $\mathrm{CMP}_{t}$ from the glycosylated forms, the purpose of the present paper was to quantify the release of these 2 groups of $\kappa$-casein fragments in renneted raw and UHT treated milks.

\section{MATERIALS AND METHODS}

\section{Milk preparation}

About 40 I of bulk whole raw milk, obtained from an industrial dairy plant (Bridel, L'Hermitage, France) were skimmed at $50^{\circ} \mathrm{C}$ with a Westfalia DD $100 \mathrm{Z}$ separator (Chateau-Thierry, France). Direct UHT treatment $\left(140^{\circ} \mathrm{C}\right.$ for $\left.10 \mathrm{~s}\right)$ was performed in a steam sterilizer (Laguilharre, RueilMalmaison, France).

\section{Determination of caseinoglycomacropeptide (CMP)}

CMP contents of milks to which were added 50 $\mu \mathrm{l}$ of rennet extract containing $520 \mathrm{mg}$ of chymosin per I for $100 \mathrm{ml}$ of sample were determined at intervals after renneting at the initial milk $\mathrm{pH}$, as indicated by Léonil and Mollé (1991) by FPLC (Mono $\mathrm{S}$ column) of its $\mathrm{pH} 4.6$ filtrate. For each point, the coefficient of variation was estimated to be $4 \%$.

\section{Characterization of the 2 fractions of $C M P_{t}$}

Ten samplings of the fractions corresponding to each peak of $\mathrm{CMP}_{\mathrm{t}}$ obtained as described by the method of Léonil and Mollé (1991) were pooled and dried in a "Speed-Vac" concentrator (Savant Inst, USA). Both dried fractions were then dissolved in $500 \mu \mathrm{l}$ of bidistilled water. On each fraction, 3 determinations were then made: firstIy, a RP-HPLC analysis on a Vydac column 218 TP 54 as described by Léonil and Mollé (1991); 
and secondly, determination of the sialic acid content according to Warren (1959); thirdly, a treatment with $0.5 \mathrm{~N} \mathrm{NaOH}$ at room temperature for $10 \mathrm{~h}$ was applied to each fraction. The release of $\alpha$-amino crotonyl residue was measured by following the increase in absorbance at $241 \mathrm{~nm}$ using a UVIKON 810 (Kontron Instruments) spectrophotometer according to the procedure of Carubelli et al (1965).

\section{Preparation of $\mathrm{CMP}_{t}$ from raw and $\mathrm{UHT}$ milks by preparative chromatography}

To $200 \mathrm{ml}$ of each milk were added $4 \mathrm{ml}$ of a rennet solution $(5 \mathrm{ml}$ of rennet extract diluted in $200 \mathrm{ml}$ of $25 \mathrm{mmol}^{-1} \mathrm{l}^{-1}$. pH 5.2 piperazine buffer). After enzyme inactivation by $15 \mathrm{ml}$ of $0.2 \mathrm{~N}$ $\mathrm{NaOH}$, both samples were treated at $60^{\circ} \mathrm{C}$ during $15 \mathrm{~min}$, then acidified to $\mathrm{pH} 4.6$ and filtered on Whatman 42. Filtrates obtained from raw or UHT milks were analyzed on a S-Sepharose Fast Flow column containing $300 \mathrm{ml}$ of exchange resin. The chromatographic analysis was performed with a Biopilot apparatus (Pharmacia, St-Quentin-en-Yvelines, France). Operating conditions were: flow rate: $1.2 \mathrm{l} . \mathrm{h}^{-1}$, eluant: $\mathrm{KCl} 20 \mathrm{mmol}^{-1}, \mathrm{pH}$ 2. Elution was obtained with a step-by-step $\mathrm{NaCl}$ gradient. Absorbance was recorded at $214 \mathrm{~nm}$. Three fractions were obtained from each filtrate, collected, dialysed on a Spectra/por PM 1000 membrane (Poly Labo, Colmar, France) and then freeze-dried.

\section{RESULTS}

\section{Characterization of both $C M P_{t}$ fractions obtained by chromatography}

The elution profile observed on Mono $\mathrm{S}$ column with a pH 4.6 filtrate obtained from renneted raw skim-milk is shown in figure 1. $\mathrm{CMP}_{t}$ is eluted in 2 peaks, noted 1 and 2. The Mono S column utilized in this study allowed a better separation of these 2 peaks than that used by Léonil and Mollé (1991). Identity of amino acid composition between these 2 fractions and reference $\mathrm{CMP}_{\mathrm{t}}$ was checked.

Figure 2 compares the RP-HPLC profiles obtained from whole $\mathrm{CMP}_{\mathrm{t}}$ and from isolated fractions 1 and 2. As already observed by Léonil and Mollé (1991), the A and $B$ genetic variants of the nonglycosylated forms of $\mathrm{CMP}_{\mathrm{t}}$ clearly appear in the elution profiles of whole $\mathrm{CMP}_{\mathrm{t}}$ (fig 2c) and fraction 2 (fig $2 b$ ). On the other hand, the elution profile of peak 1 (fig 2a) shows numerous peaks which are not well separated and with retention times that are somewhat shorter than those of the nonglycosylated molecular forms. Comparative study of figure 2 chromatograms leads to the hypothesis that peak 1 may gather glycosylated forms of $\mathrm{\kappa}$-casein macropeptide. This hypothesis was confirmed by sialic acid determination in fractions 1 and 2. They contained 0.13 and 0.006 $\mu \mathrm{mol} . \mathrm{mg}^{-1}$ of freeze-dried powder, respectively. Moreover, the alkaline treatment of each fraction led to a progressive increase of $241 \mathrm{~nm}$ absorbance in $6 \mathrm{~h}$ only for peak 1. Such a result confirms the presence of sugar derivatives bound to threonine residues through O-glycosidic linkages in the peptide chain (Carubelli et al, 1965).

\section{Influence of heat treatment of milk on the kinetics of $k$-casein hydrolysis}

Figure 3 shows kinetics of release observed for both fractions of $\mathrm{CMP}_{\mathrm{t}}$ from renneted raw and UHT milks. No significant difference between the 2 milks appears regarding to the final contents of released carbohydrate-free macropeptides (fractions 2). The found values are respectively $0.64 \mathrm{~g}^{. \mathrm{l}^{-1}}$ for raw milk and $0.65 \mathrm{~g} . \mathrm{l}^{-1}$ for UHT milk. On the contrary, initial hydrolysis rates expressed in $\mu \mathrm{mol}^{1} \mathrm{I}^{-1} \cdot \mathrm{min}^{-1}$ are significantly different and equal to 6.8 for raw milk and 5.6 for UHT milk respectively. Re- 


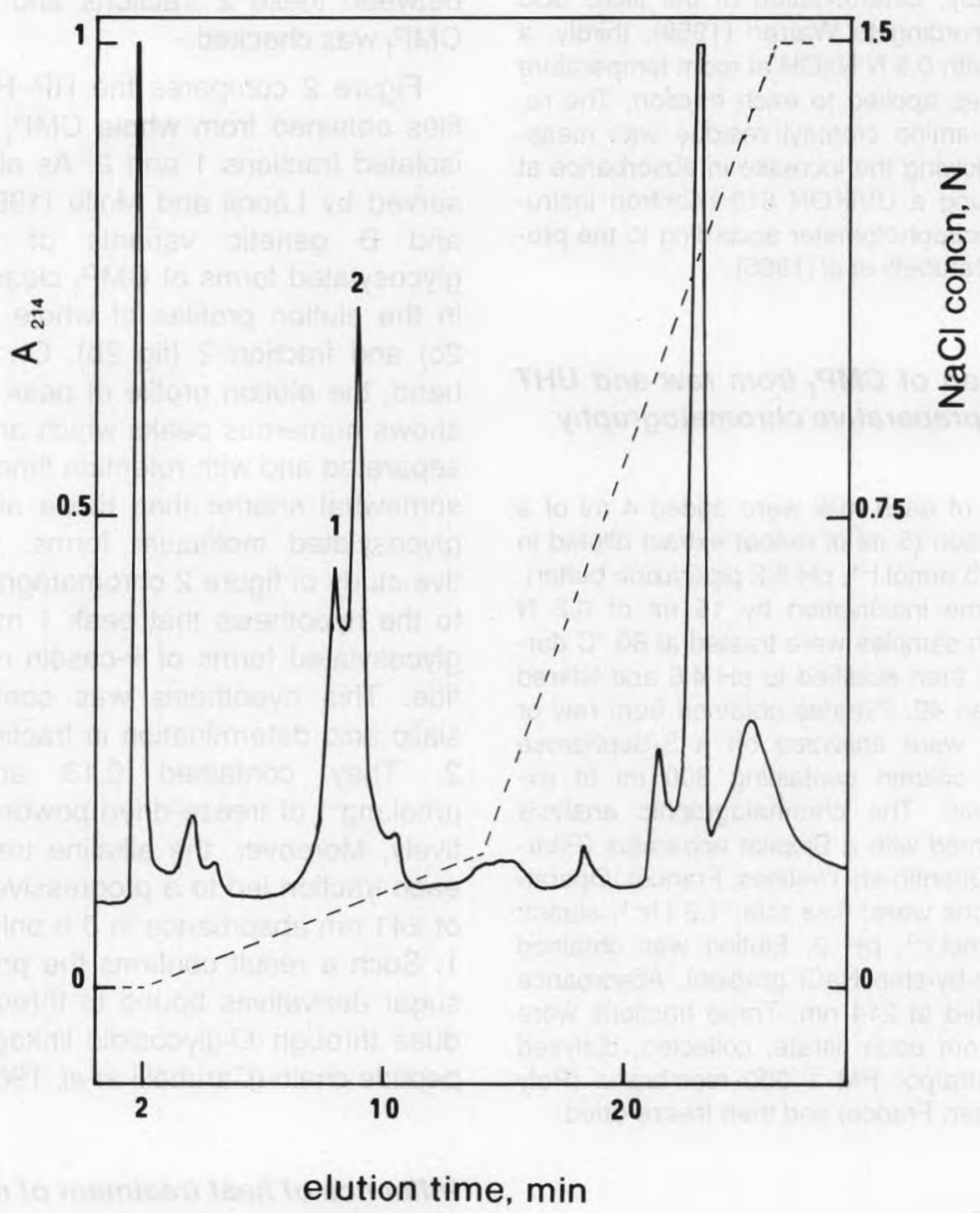

Fig 1. FPLC separation of macropeptide, by cation-exchange chromatography, obtained from $\mathrm{pH} 4.6$ filtrate, using $\mathrm{pH} 2,20 \mathrm{mmol}^{-1} \mathrm{I}^{-1} \mathrm{KCl} . \mathrm{HCl}$ buffer and a $\mathrm{NaCl}$ gradient on a Mono $\mathrm{S}$ column.

Séparation par FPLC, en chromatographie d'échange de cations, du caséinomacropeptide obtenu à partir d'un filtrat $\mathrm{pH} 4,6$, en utilisant un tampon $\mathrm{KCl} . \mathrm{HCl} 20 \mathrm{mmol}^{-\mathrm{H}^{-1}}, \mathrm{pH} 2$, sur une colonne Mono $\mathrm{S}$.

leases of glycosylated macropeptides (fractions 1) are very different. Final contents are $0.51 \mathrm{~g} . \mathrm{I}^{-1}$ for raw milk and 0.31 g. $\mathrm{I}^{-1}$ for UHT milk. This represents a $40 \%$ decrease resulting from heat treatment.
Sialic acid determination in $F_{2}$ fractions isolated by preparative chromatography from $\mathrm{pH} 4.6$ filtrates obtained from renneted raw and UHT milk (fig 4) has confirmed this value. Indeed, these $F_{2}$ fractions con- 


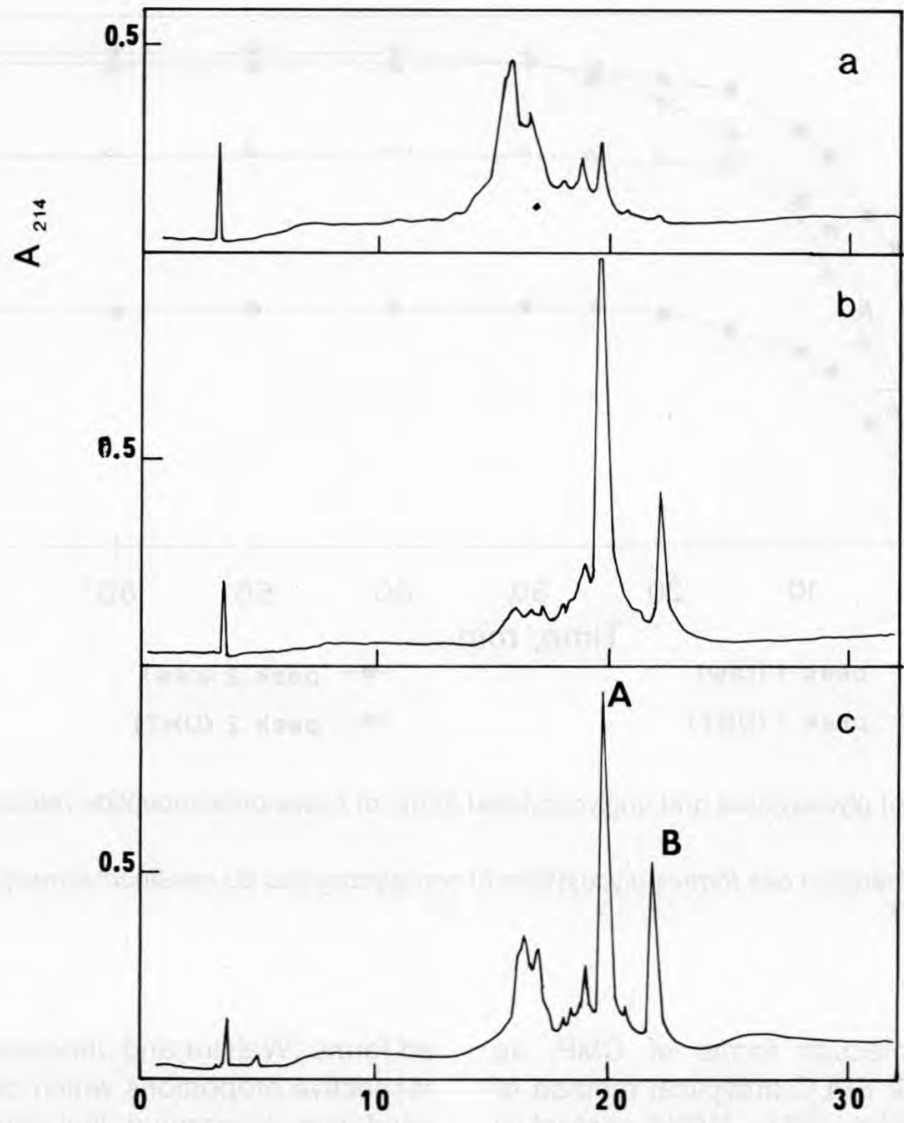

Time, $\min$

Fig 2. Elution profiles by reversed-phase HPLC on a Vydac $\mathrm{C}_{18}$ column (218TP54) of different fractions collected after cation-exchange chromatography. Elution was performed using a linear gradient from 8 to $80 \%$ acetonitrile in $0.1 \%$ trifluoroacetic acid at a flow rate of $1 \mathrm{ml} \cdot \mathrm{min}^{-1}$. a. Elution profile of peak 1 collected after cation-exchange chromatography. b. Elution profile of peak 2 collected after cation-exchange chromatography. c. Elution profile of both the peaks collected after cation-exchange chromatography. Peaks $A$ and $B$ represent carbohydrate-free macropeptide $A$ and $B$ variants respectively.

Profils d'élution en CLHP phase inverse sur une colonne Vydac $C_{18}$ (218TP54) des différentes fractions collectées après chromatographie d'échange de cations. L'élution était réalisée en utilisant un gradient linéaire de 8 à $80 \%$ d'acétonitrile dans un tampon eau/acide trifluoroacétique $0,1 \%$ à un débit de $1 \mathrm{ml} . \mathrm{mir}^{-1}$. a. Profil d'élution du pic 1 collecté après chromatographie d'échange de cations. b. Profil d'élution du pic 2 collecté après chromatographie d'échange de cations. c. Profil d'élution des 2 pics collectés après chromatographie d'échange de cations. Les pics $A$ et $B$ représentent respectivement les variants $A$ et $B$ du macropeptide non glycosylé. 


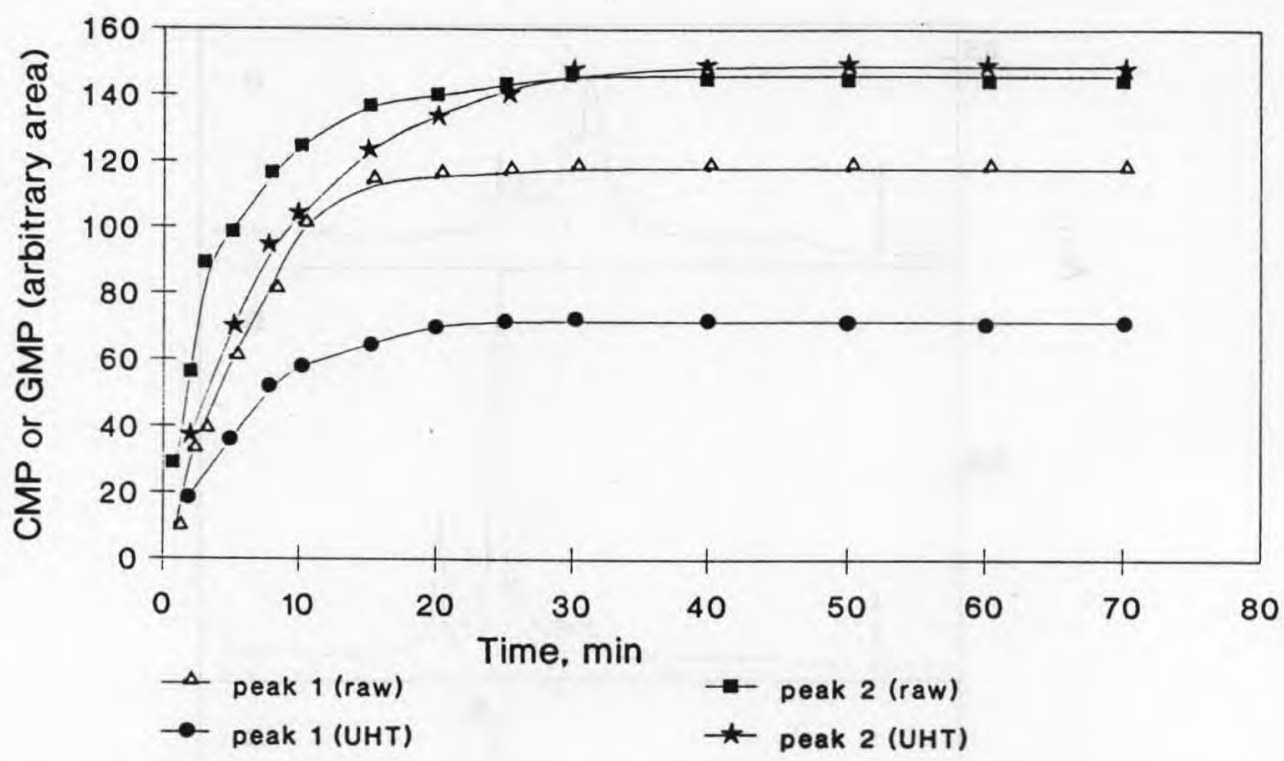

Fig 3. Kinetics of glycosylated and unglycosylated forms of caseinomacropeptide release in raw and UHT milks.

Cinétiques de libération des formes glycosylées et non glycosylées du caséinomacropeptide dans les laits crus et UHT.

tain both molecular forms of $\mathrm{CMP}_{\mathrm{t}}$ as verified by the FPLC analytical method of Léonil and Mollé (1991). NANA content of the $F_{2}$ fraction isolated from raw milk was $0.058 \mu \mathrm{mol} . \mathrm{mg}^{-1}$ against $0.032 \mu \mathrm{mol} . \mathrm{mg}^{-1}$ in the $\mathrm{F}_{2}$ fraction isolated from UHT milk. This constitutes a $45 \%$ decrease.

\section{DISCUSSION}

The new chromatographic method proposed by Léonil and Mollé (1991) allows a quantitative separation of the carbohydratefree and glycosylated forms of $\mathrm{CMP}_{\mathrm{t}}$ released during rennet hydrolysis of $\kappa$-casein. Taking into account a molecular weight of $6754 \mathrm{Da}$ for the non-glycosylated form and an average of $7280 \mathrm{Da}$ for the glycosylat- ed forms (Walstra and Jenness, 1984), the respective proportions which can be calculated from determined final contents in raw milk is $42 \%$ glycosylated and $58 \%$ nonglycosylated. These values disagree with those indicated by Walstra and Jenness (1984): $67 \%$ and $33 \%$ respectively and by Vreeman et al (1986): $60 \%$ and $40 \%$ respectively. Nevertheless, careful examination of the results of Vreeman et al (1986) shows that NANA residues were not clearly detected in $4 \mathrm{\kappa}$-casein fractions constituting $17.6 \%$ by weight of that casein. Attribution of these 4 fractions to glycosylated forms by the authors can be considered as highly speculative.

Comparison of carbohydrate-free and glycosylated CMP releases in renneted raw milk shows a slower hydrolysis of the 


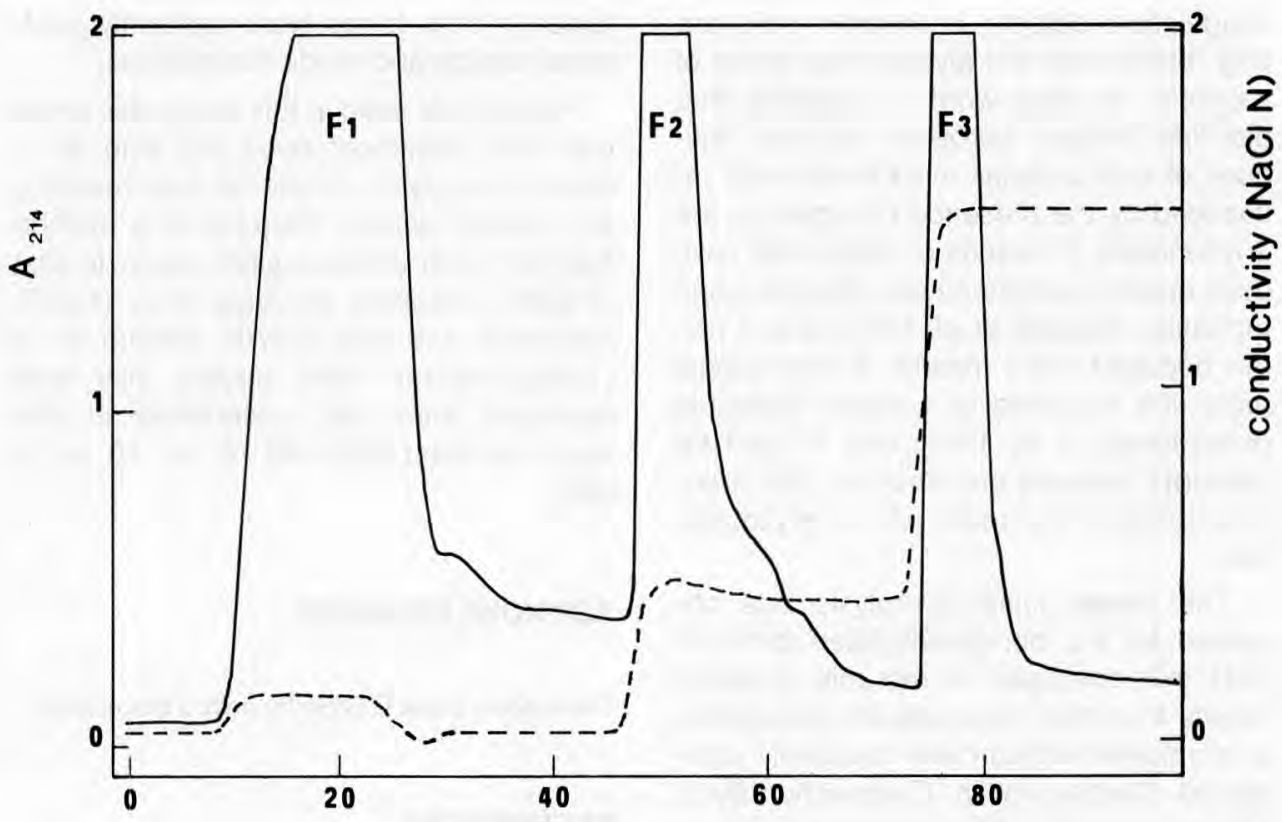

Time, $\min$

Fig 4. Elution profile of cation-exchange preparative chromatography on a S-Sepharose Fast Flow column obtained from $\mathrm{pH} 4.6$ filtrate. Operating conditions were: flow rate: $1.21 . \mathrm{h}^{-1}$, eluant: $\mathrm{pH} \mathrm{2}$, $20 \mathrm{mmol} . \mathrm{I}^{-1} \mathrm{KCl} . \mathrm{HCl}$. Elution was obtained with a step-by-step $\mathrm{NaCl}$ gradient.

Profil d'élution obtenu à partir d'un filtrat $\mathrm{pH} \mathrm{4,6}$ par chromatographie préparative d'échange de cations sur une colonne S-Sepharose Fast Flow. Les conditions opératoires étaient les suivantes : débit 1,2 I. $\mathrm{h}^{-1}$, éluant : $\mathrm{KCl} . \mathrm{HCl} 20 \mathrm{mmol}^{-1}, \mathrm{pH}$ 2. L'élution était obtenue à l'aide d'un gradient par paliers de $\mathrm{NaCl}$.

Phe $_{105}-$ Met $_{106}$ linkage in glycosylated $\kappa$-casein than in its non-glycosylated forms. Such an observation has already been made by numerous authors: Sinkinson and Wheelock, 1970; Doi et al, 1979; Fournet et al, 1979; Jollès and Fiat, 1979; Addeo et al, 1984; Van Hooydonk et al, 1984. It has been attributed to a reduced accessibility to chymosin of the glycosylated sites of $\kappa$-casein which would have higher electronegativity than the carbohydrate-free forms (Van Hooydonk et al, 1984).
UHT treatment $\left(140{ }^{\circ} \mathrm{C}\right.$ for $\left.10 \mathrm{~s}\right)$ of milk before renneting leads to a $40 \%$ decrease in glycosylated CMP release: Such a result is also in correct agreement with our former results (Ferron-Baumy et al, 1991) describing an $18 \%$ decrease in whole CMP release for the same heat treatment and a $42 \%$ proportion of glycosylated CMP determined in this study. On the other hand, the identical final contents in carbohydrate-free CMP of renneted raw and UHT milks lead to the conclusion that the $\beta$-lactoglobulin$\kappa$-casein complexes which cause rennet 
coagulation defects in heated milk are only formed with the glycosylated forms of $\kappa$-casein. In other words, it appears that disulfide bridges between cysteinyl residues of both proteins must be strongly influenced by the presence of sugars in the environment. Presence of hydrophilic residues around cysteine favors disulfide bond formation (Muskal et al, 1990) and it can be deduced from recent 3-dimensional molecular modeling of $\kappa$-casein molecule (Kumosinski et al, 1991) that 11 and 88 cysteinyl residues are close to 133 threonine residue, the main site of glycosylation.

The slower initial hydrolysis rate observed for the non-glycosylated forms in UHT milk compared to raw milk probably results from the increased electronegativity of micelles which have covalently complexed $\beta$-lactoglobulin (Dalgleish, 1990). The accessibility of the Phe-Met bonds to chymosin is consequently reduced.

This study does not allow the micellar localization of both molecular forms of $\kappa$-casein to be determined. $\beta$-lactoglobulin$\kappa$-casein complex formation caused by UHT treatment with only glycosylated forms could argue in favour of an external micellar localization. Such glycosylated $\kappa$-casein should be more accessible to $\beta$-lactoglobulin than the non-glycosylated $\kappa$-casein. Such a conclusion would be in agreement with the hypotheses put forward by Yoshikawa et al (1978), Kudo et al (1979), Walstra (1979), McGann et al (1980), Mehaia and Cheryan (1983). However, $\beta$-lactoglobulin could also penetrate the casein micelle which has a very porous structure as shown by Ribadeau Dumas and Garnier (1970). The reduced initial rates of hydrolysis by chymosin observed wit both molecular forms of $\kappa$-casein in UHT milk could also indicate an external localization of the glycosylated forms but the same results could be ob- tained if both forms were uniformly scattered outside and inside the micelles.

Results obtained in this study also show that UHT treatment does not lead to $\kappa$ casein hydrolysis similar to that resulting from rennet activity. Release of a peptide fragment with a composition close to that of $\mathrm{CMP}_{\mathrm{t}}$ observed by Alais et al (1967), Nakanishi and Itoh (1970), Khalifa et al (1985) requires more severe milk heat treatment than that undertaken in this study (at least $100-140{ }^{\circ} \mathrm{C}$ for 10 to 30 $\min )$.

\section{ACKNOWLEDGMENT}

The authors thank G Brulé for helpful discussion.

\section{REFERENCES}

Addeo F, Martin P, Ribadeau-Dumas B (1984) Susceptibility of buffalo and cow $\kappa$-caseins to chymosin action. Milchwissenschaft 39, $202-$ 205

Alais C, Kiger N, Jollès $P$ (1967) Action of heat on cow $\kappa$-casein: heat caseinoglycopeptide. J Dairy Sci 50, 1738-1743

Carubelli R, Bhavanandan VP, Gottschalk A (1965) Studies on glycoproteins. XI. The Oglycosidic linkage of $\mathrm{N}$-acetylgalactosamine to seryl and threonyl residues in ovine submaxillary gland glycoprotein. Biochim Biophys Acta 101, 67-82

Dalgleish DG (1990) The effect of denaturation of $\beta$-lactoglobulin on renneting. A quantitative study. Milchwissenschaft 45, 491-494

Doi H, Kawaguchi N, Ibuki F, Kanamori M (1979) Susceptibility of $\mathrm{K}$-casein components to various proteases. J Nutr Sci Vitaminol 25, 33-41

Ferron-Baumy C, Maubois JL, Garric G, Quiblier JP (1991) Coagulation présure des laits et des rétentats d'ultrafiltration. Effets de divers traitements thermiques. Lait 71, 423-434 
Fournet B, Fiat AM, Alais C, Jollès P (1979) Cow $\kappa$-casein: structure of the carbohydrate portion. Biochim Biophys Acta 566, 266-273

Jollès P, Fiat AM (1979) The carbohydrate portions of milk glycoproteins. J Dairy Res 46 , 187-191

Khalifa MY, Niki R, Arima S (1985) Studies on $\kappa$-casein. I. Fractionation and some properties of $k$-casein fractions. J Fac Agric Hokkaido Univ 62, 236-255

Kudo S, Iwata S, Mada M (1979) An electron microscopic study of the location of $\kappa$-casein in casein micelles by periodic acid-silver methenamine staining. J Dairy Sci62, 916-920

Kumosinski TF, Brown EM, Farrell HM (1991) Three-dimensional molecular modeling of bovine caseins: $\kappa$-caseins. J Dairy Sci 74 , 2879-2887

Léonil J, Mollé D (1991) A method for determination of glycomacropeptide by cationexchange fast performance liquid chromatography and its use for following the action of chymosin in milk. J Dairy Res $58,321-328$

McGann TCA, Donnelly WJ, Kearney RD, Buchheim W (1980) Composition and size distribution of bovine casein micelles. Biochim Biophys Acta 630, 261

Mehaia MA, Cheryan M (1983) Treatment of casein micelles with soluble and immobilized neuraminidase: implications in structure of the micelle. J Dairy Sci 66, 390-395

Muskal SM, Holbrook SR, Kim SH (1990) Prediction of the disulfide-bonding state of cysteine in proteins. Prot Eng 3, 667-672

Nakanishi T, Itoh T (1970) Studies on the changes of the milk casein by various treatments. $X$. Changes of the $\kappa$-casein solution by heat treatment. J Agric Chem Soc Jpn 44, 118-123

Reddy IM, Kinsella JE (1990) Interaction of $\beta$-lactoglobulin with $\kappa$-casein in micelles as assessed by chymosin hydrolysis: effect of temperature, heating time, $\beta$-lactoglobulin concentration and $\mathrm{pH}$. J Agric Food Chem $38,50-58$

Ribadeau-Dumas B, Garnier J (1970) Structure of the casein micelles: the accessibility of the subunits to various reagents. J Dairy Res 37 , 269-278

Schmidt DG (1982) Association of caseins and casein micelle structure. In: Developments in Dairy Chemistry. 1. Proteins (Fox PF, ed). Appl Sci Publ London, UK

Sinkinson G, Wheelock JV (1970) Carbohydrates analysis of the glycopeptides released by the action of rennin in whole milk. $J$ Dairy Res 37, 113-120

Van Hooydonk ACM, Olieman C, Hagedoorn HG (1984) Kinetics of the chymosincatalysed proteolysis of $\kappa$-casein in milk. Neth Milk Dairy J 37, 207-222

Vreeman HJ, Visser S, Slangen CJ, Van Riel JAM (1986) Characterization of bovine $\kappa$-casein fractions and the kinetics of chymosin induced macropeptide release from carbohydrate-free and carbohydrate-containing fractions determined by high performance gelpermeation chromatography. Biochem J 240 , 87-97

Walstra P (1979) The voluminosity of bovine casein micelles and some of its implications. J Dairy Res 46, 317-323

Walstra P, Jenness R (1984) Dairy Chemistry and Physics. John Wiley and Sons, New York

Warren $L$ (1959) The thiobarbituric acid assay of sialic acids. J Biol Chem 234, 1971-1975

Wheelock JV, Knight DJ (1969) The action of rennet on whole milk. J Dairy Res $36,183-$ 190

Yoshikawa M, Takahata K, Sasaki R, Chiba H (1978) Aggregation of casein micelle from bovine milk by wheat germ lectin. Agric Biol Chem 42, 1923-1926 